\title{
МОВОЗНАВСТВО
}

УДК 811.11

DOI: http://dx.doi.org/10.30970/fpl.2019.132.2917

\section{ГІПЕРО-ГІПОНІМІЧНІ ВІДНОШЕННЯ В АНГЛІЙСЬКІЙ ТЕРМІНОЛОГІї КОСМЕТОЛОГІї ТА ЕСТЕТИЧНОЇ МЕДИЦИНИ}

\author{
Ірина Бойко
}

\author{
Тернопільський національний педагогічний університет \\ імені Володимира Гнатюка, \\ вул. М. Кривоноса, 2, м. Тернопіль, Украӥна, 46000 \\ i.boiko.online@gmail.com
}

\begin{abstract}
Предметом дослідження у праці є гіперо-гіпонімічні відношення в сучасній англійській термінології косметології та естетичної медицини. Ці галузі $€$ платформами для демонстрації новітніх засобів, методів і технологій, а їхня мова, відповідно, становить актуальний матеріал термінознавчих розвідок. На основі використання лексико-семантичного аналізу та методу опозицій розглянуто родо-видові відношення між термінами зазначених галузей, а також схарактеризовано сутність лексико-семантичного явища гіперо-гіпонімії. Ідентифіковано мікрополя з англійськими термінами-гіперонімами косметології та естетичної медицини і здійснено розподіл номінацій за рівнями членування. Завдяки виокремленню гіперо-гіпонімічних зв'язків у досліджуваній термінології виявлено іiї системний характер і складну семантичну структуру.

Ключові слова: гіперо-гіпонімія, гіперо-гіпонімічні відношення, родо-видові відношення, гіперонім, гіпонім, термін, англійська термінологія косметології та естетичної медицини.
\end{abstract}

Вступ. Базисом формування будь-якої термінології є родо-видовий принцип. На позначення цього поняття існує декілька термінів, а саме: гіпонімічні, гіперо-гіпонімічні, родо-видові, суплементно-ієрархічні відношення, а також відношення включення, або імплікації. Дослідження гіперо-гіпонімічних зв'язків дає можливість осягнути мову як систему ієрархічних відношень.

За О. Селівановою, гіперонім (від грец. hyper - понад, ionyma - ім'я) - це родове поняття для певного класу понять та його мовне позначення, а гіпонім (від грец. hypo - під, iопута - ім'я) - це назва видового поняття одного класу об' єктів. Гіпонімія передбачає наявність гіпероніма й гіпонімів: перший виступає родовим позначенням класу об’єктів чи ознак, другі підпорядковуються першому як позначення видів цього класу [12]. Проте зазначимо, що гіпонімам належить більша кількість семантичних компонентів, ніж гіперонімам. Терміни, які виражають поняття видового плану, містять весь той комплекс ознак, що становить значення терміна-виразника родового поняття, а

(C) Бойко I., 2019 
також деякі додаткові значеннєві ознаки. Зміст видового поняття виявляється ширшим за зміст родового, а обсяг - вужчим [2].

Під поняттям “гіпонімія” розуміють загалом вияв мовної парадигматики, наявність у мовній системі родо-видової ієрархії позначень понять [12]. За М. Кочерганом, гіпонімія - це найбільш фундаментальні парадигматичні відношення, за допомогою яких структурують словниковий склад мови. На основі гіпонімії лексичні одиниці об'єднують у тематичні й лексико-семантичні групи і поля. Саме тому, що панівними в лексико-семантичній системі є родо-видові відношення, превалюючим типом опозицій тут є інклюзивний, тобто відношення слабкого й сильного члена. Це надає лексико-семантичній системі домінантно-підпорядкованої впорядкованості (послідовне включення слів нижчого рівня абстракції до вищого) [5].

Отже, гіпонімічна парадигма є універсальним засобом ієрархічної організації певного тематичного угрупування, яка відображає взаємозалежність між родовим і видовим поняттями. Такі зв'язки пронизують весь словниковий склад мови, будуючи при цьому складну ієрархію. Як зазначають Т. Панько зі співавторами, гіперо-гіпонімія - одна 3 найважливіших категорій, що формує термінологічні структури, виявляє ієрархію і структуру загального в речах, розкриває власне логічний, систематизуючий, класифікаційно-впорядкуючий аспекти, є універсальним засобом тематичної організації конкретної терміносистеми [7, с. 22].

3 огляду на вищенаведене, мета статті - виявити та проаналізувати характерні особливості формування системи гіперо-гіпонімічних відношень в англійській термінології косметології та естетичної медицини. Бурхливий розвиток цієї галузі, яка набула надзвичайно широкого розповсюдження у світі на початку нового тисячоліття, є прикладом швидкого розвитку новітніх технологій та глобалізаційних процесів, які зумовлюють оновлення та модифікацію наукових і професійних галузей. Косметологія та естетична медицина (надалі КЕМ) відповідають усім вимогам сьогодення. Сучасний ринок послуг косметичних салонів, лікарів-косметологів, косметологів-ін'єкціоністів, пластичних хірургів, провідних спеціалістів 3 естетичної медицини пропонує використання найновіших трендів. Ці галузі є платформами для демонстрації новітніх методів і технологій, обладнання, фармакологічних засобів, а їхня мова, відповідно, становить актуальний матеріал термінознавчих розвідок.

Аналіз останніх досліджень і публікацій. Здійснений огляд літератури підтвердив, що вже існує чимало праць, які описують явище гіпонімії на прикладі літературної мови й усталених терміносистем, наприклад: І. Волкова (українська фізична термінологія) [1], М. Гонтар (родо-видові відношення в терміносистемі журналістики) [2], О. Павлова (гіпонімія в музичній терміносистемі) [6], Г. Петрова (родо-видові відношення фітомеліоративної термінології) [8], О. Потапчук (гіперо-гіпонімічні відношення в системі економічних термінів) [9], Н. Рибалка (способи категоризації у номенклатурі ссавців) [10], Н. Руколянська (гіперо-гіпонімічні відношення в термінології кримінальнопроцесуального права) [11], Т. Соколовська (термінологія генетики) [13], О. Цобенко (структура лексико-семантичного поля “ювелірні прикраси”) [15], О. Чорна (гіперогіпонімічні відношення у податковій термінології) [16]. Проте, варто зазначити, що до сьогодні явище гіпонімії на матеріалі термінології галузей КЕМ не було об' єктом 
грунтовного системного лінгвістичного дослідження. Отже, у цій роботі здійснено спробу підтвердити, що у англійській термінології КЕМ існують гіперо-гіпонімічні відношення, які виконують роль систематизатора лексичних систем мови.

Методологія дослідження. Для досягнення мети було застосовано загальнонаукові й лінгвістичні методи, які доповнюють один одного та забезпечують належний рівень достовірності результатів. Гіперо-гіпонімічні відношення в термінології КЕМ було виявлено за допомогою лексико-семантичного аналізу, який охоплює розгляд структури значення слова, семантичних відношень лексем та їхніх лексико-семантичних і синтаксичних зв'язків. Метод опозицій застосовувався при дослідженні системних явищ КЕМ на різних рівнях для виділення різних класів мовних одиниць, завдяки чому було ідентифіковано схеми гіперо-гіпонімічних відношень.

Результати дослідження та їхнс обгрунтування. Між гіперонімами та гіпонімами простежується два види опозицій: 1) протиставлення гіперонімійного і кожного гіпонімійного значення за відсутністю / наявністю розрізнювального компонента: mask - clay mask, night mask, sheet mask; 2) протиставлення усіх співгіпонімів за змістом розрізнювального компонента значень [7]: clay mask - bentonite clay mask, fuller's earth clay mask, kaolin clay mask, French green clay mask, rhassoul clay mask. Існує два поняття для позначення цих явищ: привативні та еквіполентні опозиції, або відношення привативності й еквівалентності. Такі терміни найповніше виражають суть омовлених понять і є найточніші [7].

Еквіполентна (лат. aequipolens - рівносильний, рівноцінний) - це опозиція, усі члени якої логічно рівноправні. У межах гіперо-гіпонімічних мікрогруп це - зіставлення усіх гіпонімів гіпероніма за змістом диференційного семантичного компонента [13]. Лексично гіпоніми підпорядковані одному гіпероніму, а стосовно один одного в термінології КЕМ вони є співгіпонімами, наприклад: lipstick - matte lipstick, glitter lipstick.

Привативна опозиція - це мовна опозиція, коли один ії член відрізняється від іншого наявністю або відсутністю розпізнавальної ознаки [15]. Кількарівневу ієрархічну структуру, що грунтується на родо-видових відношеннях, утворює, наприклад, гіперонім cream. Із-поміж його гіпонімів у досліджуваній термінології зафіксовано такі, що є водночас гіперонімами до гіпонімів нового рівня: day cream - antiage day cream, young skin cream - moisture young skin cream, night cream - rejuvenating night cream.

А. Павлова з цього приводу зазначає, що семантичне відношення співгіпонімів - це відношення елементів одного класу; гіпоніми містять значеннєвий компонент (сему) гіпероніма і протиставляються один одному відповідними диференційними семами [6]. Наприклад, гіпоніми unmesurable length mascara та volume mascara утворюють еквіполентну опозицію протиставленням розрізнювальних сем. В еквіполентних опозиціях перебувають гіпоніми переважної більшості гіперо-гіпонімічних мікрогруп, наприклад: гіпоніми до гіпероніма bronzer - one tone bronzer, baked bronzer, combo bronzer; до еye shadow - wet eye shadow та dry eye shadow, pigment loose eye shadow ma color sphere eye shadow; foundation - anti-age foundation ma young skin foundation.

Асиметрія ж гіперо-гіпонімічних відношень закладена у самій структурі гіпонімії (підпорядкованість) та гіперонімії (панування). У семантичному відношенні гіпонім і 
гіперонім знаходяться у привативній опозиції типу А - не А, де гіперонім - немаркований член, а гіпонім - маркований ознакою, що конкретизує значення гіпероніма [5]. Гіпонімія характеризується привативною опозицією: видові назви завжди є семантично багатшими від родових. Саме тому, на відміну від синонімії, яка допускає взаємну заміну, гіпонімія характеризується односторонньою заміною гіпоніма на гіперонім, але не навпаки [7].

Унаслідок розвитку конкретної наукової галузі й утворення нових понять виникає потреба введення їх до наявної системи поняттєвої класифікації. Гіпоніми стають гіперонімами, утворюючи родо-видові групи на нижчому рівні узагальнення, що і спостерігаємо у термінології КЕМ. Наприклад, гіперонім therapy має такі гіпоніми: laser therapy, cryotherapy, vacuum therapy, electrotherapy, vibrotherapy, ultrasound therapy, pressure therapy, IPL-Pulsed light therapy, magnetotherapy. Водночас термін laser therapy $\epsilon$ гіперонімом до гіпоніма laser shower therapy; термін electrotherapy $є$ гіперонімом до гіпоніма electro-acupuncture therapy; термін vacuum therapy установлює гіперогіпонімічні відношення з термінами-гіпонімами cellulite vacuum therapy, anti wrinkle vacuum therapy.

Услід за Д. Лотте, використовуємо “основні правила поділу понять, які перебувають у родо-видових відношеннях: 1) підстава поділу (тобто ознака, за якою відбувається поділ обсягу поняття) повинна лишатися однією й тією самою під час утворення будьякого видового поняття; 2) обсяги видових понять повинні вичерпувати обсяг родового поняття" [4, с. 29]. Оскільки гіперонімом може бути поняття, схарактеризоване 3 різних боків і конкретизоване за різними критеріями, то гіпоніми групуємо не в одне велике родо-видове утворення, а на основі одного гіпероніма утворюємо кілька гіперо-гіпонімічних груп на підставі різних розрізнювальних класифікаційних ознак, кожна з яких є підставою поділу родового поняття на видові і слугує об'єднувальним чинником групи. Наприклад, термін brush є гіперонімом у таких групах: пензлики для нанесення бази (makeup brushes for base): foundation brush, stippling brush, powder brush, bronzer brush, concealer brush, mineral powder brush, fan powder brush; пензлики для щік та вилиць (makeup brushes for cheeks): blusher brush, angled blush brush, face contour brush; пензлики для очей (makeup brushes for eyes): eyeshadow brush, angle eye brush, blending eye brush, eyeliner brush; пензлики для брів (makeup brushes for brows): 2-in-1 defining brush, eyebrow definer brush, spiral eyebrow brush; пензлики для губ (makeup brushes for lips): lip brush, retractable lip brush, defining lip brush. Право утворювати різні родо-видові групи від одного родового поняття “дає змогу подати розгорнуту семантичну структуру поняття, представити незафіксовані в дефініції видові значення" [11, с. 119].

Гіперо-гіпонімічні відношення призводять до утворення мікрополів. Мікрополем $\epsilon$ лексико-семантична група - відносно замкнений ряд лексичних одиниць однієї частини мови, об'єднаних конкретним змістом [9]. Наприклад, у мікрополі з гіперонімом “skin”" виокремлюємо dry skin, oily skin, problem skin, sensitive couperose-prone skin, normal skin, а у мікрополі з гіперонімом “mesotherapy" - face mesotherapy, body mesotherapy, hair and head skin mesotherapy. 
У деяких мікрополях термінології КЕМ можна виділити номінації з декількома рівнями членування, наприклад у мікрополі з гіперонімом “peel” виокремлюємо: 1) номінації з одним рівнем членування: mechanical peel, chemical peel, enzyme peel; 2) номінації з двома рівнями членування: chemical peel - superficial chemical peel, medium chemical peel, deep chemical peel; 3) номінації з трьома рівнями членування: chemical peel - alpha-hydroxy acids (AHAs) superficial chemical peel, (BHA) beta hydroxy acids superficial chemical peel.

У мікрополі з гіперонімом "lift” можна виділити: 1) номінації з одним рівнем членування: eyelid lift, endoscopic lifting, filament lifting, hardware lift; 2) номінації $з$ двома рівнями членування: hardware microcurrent lift, hardware ultrasound lift, hardware laser lift. У мікрополі з гіперонімом “implant” виділяємо: 1) номінації з одним рівнем членування: silicone implant, saline implant; 2) номінації з двома рівнями членування: silicone breast implant, silicone lip implant, silicone buttocks implant.

У мікрополі з гіперонімом “cream” ідентифікуємо: 1) номінації з одним рівнем членування: soothing cream, smoothing cream, day and night cream, anti-wrinkle eye cream, anti-aging cream, moisturizing cream, rejuvenating cream, care cream; 2) номінації $з$ двома рівнями членування: smoothing cream, face smoothing cream, hand smoothing cream.

У процесі конкретизації родового поняття розрізняємо гіперо-гіпонімічні групи з паралельним і послідовним підпорядкуванням. Якщо одному гіпероніму підпорядковано кілька гіпонімічних підгруп, об'єднаних за різними ознаками, таке структурування називається паралельним (рис. 1.).

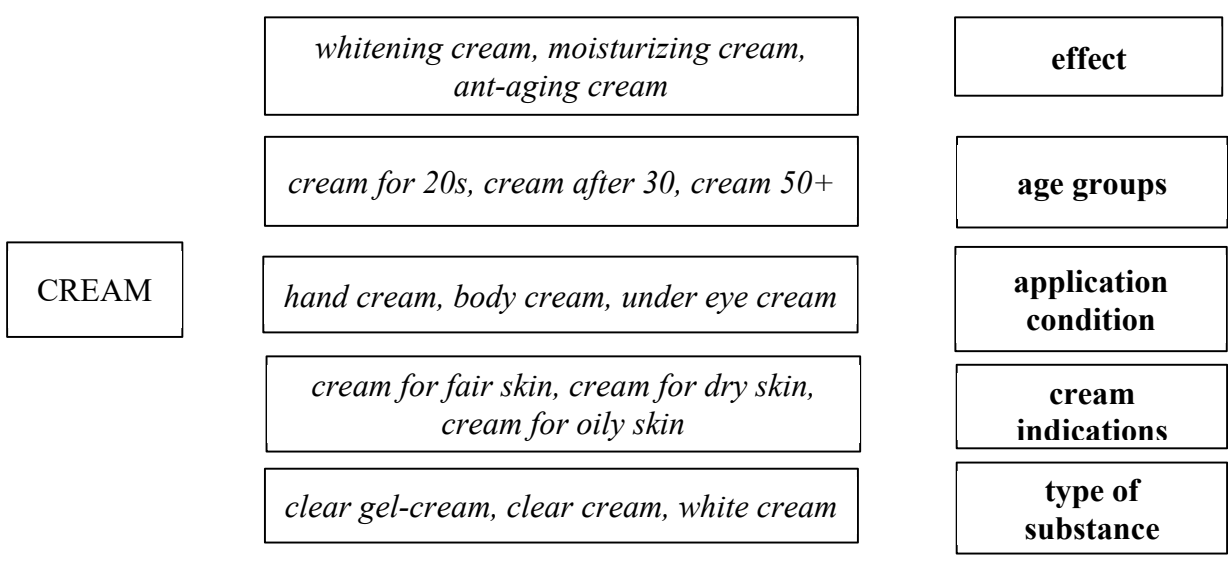

Рис. 1. Гіперо-гіпонімічна група терміна “cream” з паралельною структурою

Терміни попереднього рівня виступають родовими для термінів наступного рівня у послідовних структурах (рис. 2). 


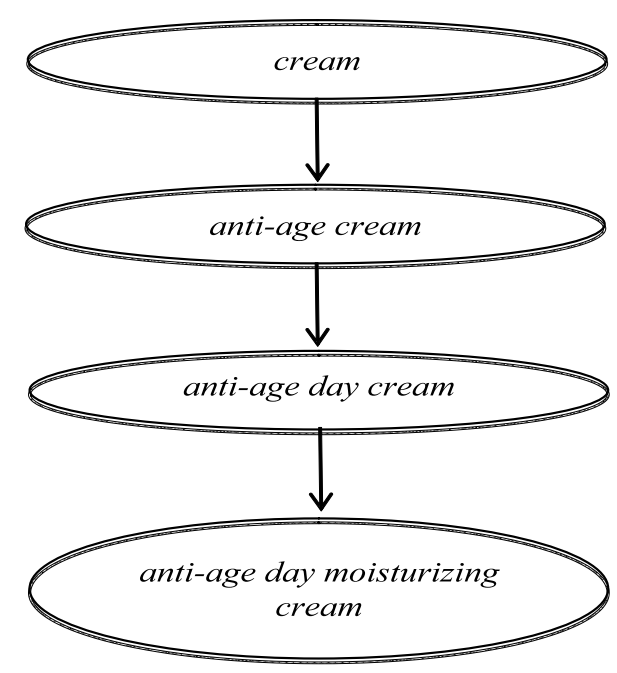

Рис. 2. Гіперо-гіпонімічна група з послідовною структурою

Гіперо-гіпонімічні структури можуть розгортатися як за вертикаллю, так і за горизонталлю. Основою відношень між членами вертикального ряду є відношення підпорядкування, а горизонтального семантична рівність. Наприклад, термін makeup конкретизують два гіпоніми, які розміщені на горизонтальному рівні: everyday makeup, special event makeup. Термін-гіпонім special event makeup одночасно $є$ гіперонімом для таких термінів: bridesmaid makeup, bridal makeup, Christmas makeup, harlequin makeup, harajuku makeup, 1940s makeup, 80s makeup, avant garde makeup. Термінгіпонім everyday makeup одночасно $\epsilon$ гіперонімом для термінів hypoallergenic makeup products, instant tan makeup, makeup suggestions for women over 50, permanent

makeup. Термін-гіпонім permanent makeup одночасно є гіперонімом для наступних терміноодиниць: lip color permanent makeup, eye liner permanent makeup, eyebrow filling permanent makeup, reconstructive permanent makeup.

Термін lipstick конкретизують гіпоніми lipstick effect, lipstick formula, які розміщенні на одній горизонталі. Вони утворюють перший ступінь конкретизації. Термін-гіпонім lipstick effect одночасно $є$ гіперонімом для таких термінів: glitter lipstick, glossy lipstick, matte lipstick, metallic lipstick, sheer lipstick, shimmer lipstick. Термін-гіпонім lipstick formula одночасно є гіперонімом для cream, liquid, pencil lipstick, powder lipstick, solid. Зазначимо, що хоча поняття об'єднанні між собою гіперо-гіпонімічною залежністю, вони утворюють групи різної структури.

Висновки та перспективи подалыших досліджень. Проведений аналіз фактичного матеріалу виявив, що термінології КЕМ притаманні гіперо-гіпонімічні відношення, які відіграють важливу роль у систематизації та тлумаченні значень досліджуваних термінів. Вони зумовлюють чітке розмежування понять, забезпечують ієрархічний характер термінології КЕМ і сприяють ії збагаченню.

Також було виявлено багаторівневу семантичну структуру термінології КЕМ, яка свідчить про еволюцію обраних для дослідження галузей і дає змогу констатувати високий ступінь структурованості і логічної зв'язності досліджуваної термінології.

У сучасний період інтеграції наук у зв'язку з глобалізацією англійська термінологія КЕМ активно проникає в українську мову і зумовлює постійний пошук відповідників. Вступаючи у відносини гіперо-гіпонімії, запозичені терміни КЕМ формують міцні парадигматичні зв'язки в лексико-семантичній системі сучасної української мови. Тому перспективою подальших досліджень може стати порівняльний аналіз англійської та української термінологій КЕМ. 


\section{СПИСОК ВИКОРИСТАНОї ЛІТЕРАТУРИ}

1. Волкова I. В. Гіперо-гіпонімічні відношення в сучасній українській фізичній термінології / І. В. Волкова // Вісник Харківського національного університету ім. В. Н. Каразіна. - Харків, 2006. - № 745. - Вип. 49. - С. 27-30.

2. Гонтар М. Родо-видові відношення в терміносистемі журналістики / М. Гонтар // Вісник Національного університету “Львівська політехніка": Проблеми української термінології. - Львів, 2010. - № 675. - С. 83-86.

3. Искаринова С. И. Гипо-гиперонимия как тип регулярной лексической полисемии / С. И. Искаринова // Вопросы функциональной лексикологии: межвуз сб. научн. тр. Москва : МГПИ им. В. И. Ленина, 1987. - С. 78-86.

4. Как работать над терминологией. Основы и методы : [пособие сост. по трудам Д. С. Лотте и Ком. науч-техн. терминологии АН СССР]. Москва : Наука, 1968. - 76 с.

5. Кочерган М. П. Загальне мовознавство : підручник. [2 вид., випр. і доп.] / М. П. Кочерган Київ : Академія, 2006. - 464 с.

6. Павлова О. І. Гіпонімія в музичній терміносистемі англійської, французької, російської та української мов / О. І. Павлова. - Вісник Дніпропетр. ун-ту. Серія "Мовознавство”. - Дніпропетровськ : Вид-во Дніпропетровського ун-ту, 2009. - Вип. 15 / № 11. - Т. 2. - С. 113-119.

7. Панько Т. І. Українське термінознавство : підруч. [для студ. гуманітар. спец. вищ. навч. закл.] / Т. І. Панько, І. М. Кочан, Г. П. Мацюк. - Львів : Світ, 1994. - 216 с.

8. Петрова Т. О. Родо-видові відношення в комбінованому словнику фітомеліоративної термінології / Т. О. Петрова // Термінологічний вісник: зб. наук. праць: у 2-х ч. - Київ: Ін-т укр. мови НАН України, 2015. - Вип. 3 (1). - С. 141-150.

9. Потапчук О. Гіперо-гіпонімічні відношення в системі економічних термінів / О. Потапчук // Науковий вісник Східноєвропейського національного університету імені Лесі Українки: Філологічні науки. Мовознавство. - 2014. - №2. - С. 57-62.

10. Рибалка Н. С. Гіперонімічний та еквонімічний різновиди мотивації як відображення способів категоризації у номенклатурі ссавців / Н. С. Рибалка // Записки з романо-германської філології: зб. наук. праць. - Одеса, 2009. - Вип. 24. - С. 221-228.

11. Руколянська Н. Гіперо-гіпонімічні відношення в термінології кримінально-процесуального права / Н. Руколянська // Українська термінологія і сучасність: зб. наук. праць. Київ, 2007. - Вип. VII. - С. 118-120.

12. Селіванова О. Сучасна лінгвістика: термінологічна енциклопедія / О. Селіванова. Полтава : Довкілля-К, 2006. - 716 с.

13. Соколовська Т. Г. Українська термінологія з генетики: походження, структура, системність (лінгвістична проблематика) : автореф. дис. на здобуття наук. ступеня канд. філол. наук: спец. : 10.02.01 "Українська мова" / Т. Г. Соколовська. - Київ, 1999. - 20 с.

14. Сучасний словник іншомовних слів: близько 20 тис. слів і словосполучень. Укл.: О. І. Скопненко, Т. В. Цимбалюк. - Київ : Довіра, 2006. - 789 с.

15. Цобенко О. В. Структура лексико-семантичного поля “ювелірні прикраси” в англійській мові / О. В. Цобенко // Записки з романо-германської філології. - 2014. Вип. 1. - C. 192-197. - Режим доступу : http://nbuv.gov.ua/UJRN/ zrgf_2014_1_29.

16. Чорна О. Гіперо-гіпонімічні відношення у податковій термінології / О. Чорна // Українська термінологія і сучасність: зб. наук. праць. - Київ, 2009. - Вип. VIII. C. 102-106. 


\section{REFERENCES}

1. Volkova I. V. Hipero-hiponimichni vidnoshennia $\mathrm{v}$ suchasnii ukrainskii fizychnii terminolohii [Hypero-hyponimic relations in modern Ukrainian physical terminology] / I. V. Volkova // Visnyk Kharkivskoho natsionalnoho universytetu im. V. N. Karazina. Kharkiv, 2006. - № 745. - Vyp. 49. -S. 27-30.

2. Hontar M. Rodo-vydovi vidnoshennia $v$ terminosystemi zhurnalistyky [General-specific relations in the terminological system of journalis] / M. Hontar // Visnyk Natsionalnoho universytetu "Lvivska politekhnika": Problemy ukrainskoi terminolohii. - Lviv, 2010. - № 675. - S. 83-86.

3. Iskarinova S. I. Gipo-giperonimija kak tip reguljarnoj leksicheskoj polisemii [Hypo-hyperonymy as a type of regular lexical polysemy] / S. I. Iskarinova // Voprosy funkcional'noj leksikologii: mezhvuz sb. nauchn. tr. Moskva : MGPI im. V. I. Lenina, 1987. - S. 78-86.

4. Kak rabotat' nad terminologiej. Osnovy i metody : [posobie sost. po trudam D. S. Lotte i Kom. nauch-tehn. terminologii AN SSSR] [How to work with terminology: Fundamentals and methods]. - Moskva : Nauka, 1968. - $76 \mathrm{~s}$.

5. Kocherhan M. P. Zahalne movoznavstvo : pidruchnyk. [2 vyd., vypr. i dop.] [General linguistics: A textbook] / M. P. Kocherhan. - Kyiv : Akademiia, 2006. - 464 s.

6. Pavlova O. I. Hiponimiia v muzychnii terminosystemi anhliiskoi, frantsuzkoi, rosiiskoi ta ukrainskoi mov [Hyponymy in the musical terminology of English, French, Russian, and Ukrainian] / O. I. Pavlova //Visnyk Dnipropetr. un-tu. Seriia "Movoznavstvo". Dnipropetrovsk : Vyd-vo Dnipropetrovskoho un-tu, 2009. - Vyp. 15 / № 11. - T. 2. - S. 113-119.

7. Panko T. I. Ukrainske terminoznavstvo : pidruch. [dlia stud. humanitar. spets. vyshch. navch. zakl.] [Ukrainian terminological studies: A textbook] / T. I. Panko, I. M. Kochan, H. P. Matsiuk. - Lviv : Svit, 1994. - 216 s.

8. Petrova T. O. Rodo-vydovi vidnoshennia v kombinovanomu slovnyku fitomelioratyvnoi terminolohiiof [General-specific relations in the combined dictionary of phytomeliorative terminology] / T. O. Petrova // Terminolohichnyi visnyk: zb. nauk. prats: u 2-kh ch. Kyiv: In-t ukr. movy NAN Ukrainy, 2015. - Vyp. 3 (1). - S. 141-150.

9. Potapchuk O. Hipero-hiponimichni vidnoshennia v systemi ekonomichnykh terminiv [Hypero-hyponymic relations in the system of economic terms] / O. Potapchuk // Naukovyi visnyk Skhidnoievropeiskoho natsionalnoho universytetu imeni Lesi Ukrainky: Filolohichni nauky. Movoznavstvo. - 2014. - № 2. - S. 57-62.

10. Rybalka N. S. Hiperonimichnyi ta ekvonimichnyi riznovydy motyvatsii yak vidobrazhennia sposobiv katehoryzatsii u nomenklaturi ssavtsiv [Hyperonymic and ekvonymic types as the reflection of the ways of categorization and nomenclature of mammals] / N. S. Rybalka // Zapysky z romano-hermanskoi filolohii: zb. nauk. prats. Odesa, 2009. - Vyp. 24. - S. 221-228.

11. Rukolianska N. Hipero-hiponimichni vidnoshennia $\mathrm{v}$ terminolohii kryminalnoprotsesualnoho prava [Hypero-hyponymic relations in the terminology of criminal procedure law] / N. Rukolianska. - Ukrainska terminolohiia i suchasnist: zb. nauk. prats. Kyiv, 2007. - Vyp. VII. - S. 118-120.

12. Selivanova O. Suchasna linhvistyka: terminolohichna entsyklopediia [Modern linguistics: A terminological encyclopedia] / O. Selivanova. - Poltava : Dovkillia-K, 2006. - $716 \mathrm{~s}$.

13. Sokolovska T. H. Ukrainska terminolohiia z henetyky: pokhodzhennia, struktura, systemnist [Ukrainian terminology of genetics: genesis, structure, systematicity] / T. H. Sokolovska : avtoref. dys. na zdobuttia nauk. stupenia kand. filol. nauk: spets. : 10.02.01 "Ukrainska mova". - Kyiv, 1999. - 20 s.

14. Suchasnyi slovnyk inshomovnykh sliv: blyzko 20 tys. sliv i slovospoluchen [Contemporary dictionary of foreign words: about 20,000 words and word-combinations] / Eds. O. I. Skopnenko, T. V. Tsymbaliuk. - Kyiv : Dovira, 2006. - 789 s. 
15. Tsobenko O. V. Struktura leksyko-semantychnoho polia "iuvelirni prykrasy" v anhliiskii movi [Structure of the lexical and semantic field "jewellery" in English] / O. Tsobenko // Zapysky z romano-hermanskoi filolohii. 2014. - Vyp. 1. - S. 192-197. - Access mode : http://nbuv.gov.ua/UJRN/ zrgf_2014_1_29.

16. Chorna O. Hipero-hiponimichni vidnoshennia u podatkovii terminolohii [Hypero-hyponymic relations in tax terminology] / O. Chorna // Ukrainska terminolohiia i suchasnist: zb. nauk. prats. - Kyiv, 2009. - Vyp. VIII. - S. 102-106.

\title{
HYPER-HYPONYMIC RELATIONS IN THE ENGLISH TERMINOLOGY OF COSMETOLOGY AND AESTHETIC MEDICINE
}

\author{
Iryna Boiko
}

\author{
Ternopil Volodymyr Hnatiuk National Pedagogical University, \\ 2, M. Kryvonosa Str., Ternopil, Ukraine, 46000 \\ i.boiko.online@gmail.com
}

The objective of this paper is to study hyper-hyponymy in the English terminology of cosmetology and aesthetic medicine. The general-specific relations between the terms are considered, and the essence of the lexical-semantic phenomenon of hyper-hyponymy is characterized. The research is based on the combination of the lexical and semantic analysis and opposition method, which appear to be the most suitable for the present study.

In the process of specifying the generic concept, hyper-hyponymic groups with parallel and consistent subordination are differentiated. Hyper-hyponymic structures can be seen as both vertical and horizontal. The basis of relations between the members of the vertical row is subordination, and of the horizontal one - semantic equality.

The systemic character and semantic structural features of the terminology of cosmetology and aesthetic medicine are determined by distinguishing hyper-hyponymic relations. By the example of these English terms, two types of oppositions are identified (equipolar and private oppositions). Based on the analysis of theoretical sources, it was found out that hyper-hyponymic relations lead to the formation of microfields, which combine lexical units of one part of speech with the same content. The microfields with the termshyperonyms (such as mask, lipstick, cream, bronzer, therapy, brush, skin, peel, lift, makeup) have been identified. The distribution of nominations on different levels has been considered; namely, the following types of nominations have been revealed: 1) nominations with one level of distribution; 2) nominations with two levels of distribution.

Today, in the period of science integration, caused by globalization, the English terminology of cosmetology and aesthetic medicine actively penetrates into Ukrainian life. While establishing the hyperhyponymic relations, English terms acquire strong paradigmatic connections in the lexical and semantic system of the modern Ukrainian language. This phenomenon determines the need to pursue contrastive studies of English and Ukrainian terms in the fields of cosmetology and aesthetic medicine.

Key words: hyper-hyponymy, hyper-hyponymic relations, general-specific relations, hyperonym, hyponym, term, English terminology of cosmetology and aesthetic medicine. 